\title{
Globally Declining Population of Women Folk Causing Sex Imbalance Is a Serious Concern: An Analysis of Sex Ratio around the Globe
}

\author{
Rajesh K. Gautam, ${ }^{1}$ Jyoti Jhariya, ${ }^{1}$ and Pardeep Kumar ${ }^{2}$ \\ ${ }^{1}$ Department of Anthropology, Dr. H.S. Gour University, Sagar 470003, India \\ ${ }^{2}$ University of Delhi, Delhi 110007, India \\ Correspondence should be addressed to Rajesh K. Gautam; goutamraj@rediffmail.com
}

Received 17 February 2015; Accepted 17 April 2015

Academic Editor: Santos Alonso

Copyright (C) 2015 Rajesh K. Gautam et al. This is an open access article distributed under the Creative Commons Attribution License, which permits unrestricted use, distribution, and reproduction in any medium, provided the original work is properly cited.

\begin{abstract}
Successful existence and perpetuation of any species depend on its reproductive success. In case of humans, the theoretical proportion of males and females should be $1: 1$, but this equilibrium was disturbed in many parts of the world. What are the determinants of sex imbalance in human should be found out to combat the problem. The data were gathered for 227 countries. The sex ratio for human population of the world was found 101 males for 100 females, but it varies from 74 to 219 among the countries. The number of countries having higher number of females as compared to males is 132, as they have 99 or less males per 100 females, whereas in 71 countries the total population of males is greater than the females. And only 24 countries have balanced sex ratio. Regression analysis shows that fertility, rate of natural increase, mortality, and gender inequality index have inverse effect, and they account for $24.4 \%, 23.1 \%, 18.8 \%, 18.9 \%, 16.3 \%, 16.1 \%$, and $5.1 \%$ of variability, respectively. There is great need to identify such countries and region where sex selective abortion is being practiced and to find out appropriate strategies to combat such problem.
\end{abstract}

\section{Introduction}

For perpetuation and continuous existence of any species, it is essential that the process of reproduction should be continuous. And, for continuous reproduction, there must be sufficient number of eligible couples or, in other words, there should be balance between the sexes of mating population, which varies from species to species. In some species, it is unbiased; there is equal allocation of resources in both the sexes, whereas, in others, it is either male or female biased [1-4]. Facultative sex ratio variation was reported among organisms with chromosomal sex determination [5]. There can be shifts in offspring sex ratios consistent with adaptation [4, 6-14]. Selection also operates on the sex ratio [5].

Traditionally, farmers have discovered that the most economically efficient community of animals will have a large number of females and a very small number of males. A herd of cows with a few prize bulls or a flock of hens with one rooster are the most economical sex ratios for domesticated livestock. In similar way, among natural population too, polyandry can be seen among some of the birds, insects, and monkeys [1]. These creatures increase the rate of reproductive success by such mechanism of cooperative breeding. Postcopulation mating with multiple males increases the survival of the female's offspring, as all mating partners care for offspring in expectation of securing own DNA. It is also reported that $61 \%$ of Saddleback Tamarins (Primate) have polyandrous union. Polyandry was also reported among human population [15-19], where a polyandrous union is a cooperative mode of life in the difficult environmental condition.

Gender imbalance may arise as a consequence of various factors ranging from natural incidents, war casualties, gender control, and deliberate gendercide. By nature, in human being, slightly more males are born than females; therefore the sex ratio at birth is 105 or 106 males per every 100 females. The difference in sex ratio at birth has arisen naturally because of difference in mass of sperm carrying $\mathrm{X}$ - and 
Y-chromosome. The sperms, carrying Y chromosome, are comparatively lighter than the other. Being lighter in mass, it can move faster and reach early to egg. Therefore sex ratio at birth is higher. On the other hand, it is quite common for males to experience higher mortality virtually at all ages after birth. Yet, during last one century, it is being observed that, in some parts of the world, the population of women folk at birth and population in total are declining rapidly. In general, more males are born but females experience lower mortality. In this way, during childhood, males outnumber females of the same age. The difference decreases as the age increases and in the adult life span, the numbers of males and females become equal, and as age increases the number of females becomes disproportionately large.

The sex ratio within a population has significant implications for marriage patterns. If there is sex imbalance in any society, especially among population of marriageable age, a proportion of population will remain without mate, or mate may be shared (legally or illegally) with more than one individual, which may cause many social, health, and behavioral problems like HIV-AIDS, prostitution, homosexuality, kidnapping, rape, murder, and so forth. It may also decline the fertility.

There is no information about sex ratio of early man or human being of prehistoric era. But it can be assumed that it would have been 1:1 for total population. The reason behind this assumption is that the key agent of sex is produced in equal numbers. This key agent is sperms carrying Xchromosome and Y-chromosome. So, in most of the sexual species, the population of males and females are theoretically equal in proportion $(1: 1)$. This is also essential to compensate the higher male mortality of early ages. It can be further assumed that during reproductively active period of life, that is, 15-45 years, the sex ratio of total population would be $1: 1$ approximately. But, this natural arrangement is disturbed with the advancement of medical science and introduction of ultrasound technology. The advancement of medical science especially the techniques of prenatal sex determination has proven as a boon for the parents have strong preference for son, and, female feticide started, as the sex selective abortion became possible and reliable; however, female infanticide already exists in many parts of the world, with special reference to Indian society. Sex selective international migration is also one of the important determinants of sex imbalance.

In this background, there is an attempt to understand the extent of sex imbalance around the globe, simultaneously to find out the determinants of sex imbalance in human population.

\section{Material and Methods}

The present study is based on information collected from Census Reports, World Fact Sheet, Data Sheet of Population Reference Bureau (PRB), Human Development Report, and other reliable sources. Initially, the data obtained from different sources was cross-checked for their reliability. The data on sex ratio was gathered for 227 countries of the globe. The data of human development index was available for 183 countries. Similarly, the data on gender inequality index was available for 143 countries. All the data was for the year of 2011. For further editing, all the data was entered into an excel worksheet and it was filtered. Some of the calculations were also made in excel worksheet. Thereafter, the data was transferred to SPSS software for further calculation and analysis.

\section{Results}

To understand the sex imbalance among humans, the sex ratio of 227 countries was critically reviewed in terms of number of males per 100 females at birth (Table 1), for population below 15 years of age, 15-64 years of age, 65+ years of age, and for total population. During this exercise, it was found that highest number of male children born per 100 females was 113 for China, whereas lowest number of 101 male children per 100 girls was recorded for Haiti (Caribbean), Barbados (Caribbean), and Liechtenstein (Europe). None of the countries had less than hundred male children at birth for 100 female children. It is evident from Table 2 that in 155 countries the sex ratio at birth is $\leq 105$, whereas 72 countries have sex ratio $\geq 106$ at birth.

The analysis of sex ratio of population below 15 years of age indicates that it generally declined as compared to sex ratio at birth. It was found that, in 138 countries, the number of males per 100 females declined from 1 to 11, whereas it increased in 22 countries. In 55 countries, there was no change in sex ratio at birth and among the population of $0-15$ years of age.

The sex ratio of population of 15 to 64 years of age group is crucial as most of them are reproductively and sexually active. The analysis indicates that 100 countries have less number of women as the sex ratio is greater than 101. Most distorted sex ratio in this age group was reported for Asian countries like Saudi Arabia (129), Bahrain (133), Oman (138), Maldives (162), Kuwait (178), Qatar (246), and United Arab Emirates (274). One of the countries of Oceania, that is, Palau (126), also has similar distorted sex ratio. Further analysis indicates that, in 127 countries, there are higher numbers of females as compared to males. In this age group, the sex ratio is equal to or less than 100. Lowest numbers of males per 100 females were reported for Northern Mariana Islands (67).

The sex ratio of aged people, 65+ years of age group, has reverse trend. In most of the countries, there are higher numbers of females as compared to males. Out of 227 countries, 210 have sex ratio $\leq 99$ males per 100 females including India, China, and other highly populated countries, whereas only 17 countries have sex ratio $\geq 100$ males for 100 females.

The sex ratio for total population of the world is 101 males for 100 females, but it varies from 74 to 219 among the countries. The number of countries having higher number of females as compared to males is 132, as they have 99 or less males per 100 females, whereas in 71 countries the total population of males is greater than the population of females as they have 101 or more males per 100 females. And only 24 countries have balanced sex ratio as they have equal number of males and females for total population. 
TABle 1: Sex ratio at birth around the globe.

\begin{tabular}{|c|c|c|}
\hline Sex ratio at birth & Name of countries & $\begin{array}{c}\text { Number of } \\
\text { countries }\end{array}$ \\
\hline 101 & Barbados, Haiti, Liechtenstein & 3 \\
\hline 102 & Aruba, Bermuda, Cayman Islands, Kenya, Malawi, Mozambique, South Africa & 7 \\
\hline 103 & $\begin{array}{l}\text { Anguilla, Bahamas, Bahrain, Botswana, Burkina Faso, Burundi, Cameroon, Cape } \\
\text { Verde, Central African Republic, Comoros, Congo (the Democratic Republic), } \\
\text { Republic of the Congo, Cote d'Ivoire, Djibouti, Equatorial Guinea, Eritrea, Ethiopia, } \\
\text { Gabon, Gambia, Ghana, Guinea, Guinea-Bissau, Lesotho, Liberia, Madagascar, } \\
\text { Mali, Mauritania, Mayotte, Montserrat, Namibia, Niger, Rwanda, Saint Vincent and } \\
\text { the Grenadines, Sao Tome and Principe, Senegal, Seychelles, Sierra Leone, Somalia, } \\
\text { Swaziland, Tanzania, Togo, Trinidad and Tobago, Uganda, Zambia, Zimbabwe }\end{array}$ & 45 \\
\hline 104 & $\begin{array}{l}\text { Bangladesh, Chad, Dominican Republic, Finland, Iceland, Kuwait, Nepal, Panama, } \\
\text { Saint Martin, Sri Lanka, Uruguay, Western Sahara }\end{array}$ & 12 \\
\hline 105 & $\begin{array}{l}\text { Afghanistan, Algeria, Angola, Antigua and Barbuda, Argentina, Austria, Belgium, } \\
\text { Belize, Benin, Bhutan, Bolivia, Brazil, British Virgin Islands, Brunei, Cambodia, } \\
\text { Chile, Cook Islands, Costa Rica, Cyprus, Dominica, Ecuador, Egypt, El Salvador, } \\
\text { Fiji, France, French Polynesia, Greenland, Guatemala, Guernsey, Guyana, } \\
\text { Honduras, Indonesia, Iran, Iraq, Isle of Man, Israel, Jamaica, Kiribati, Kyrgyzstan, } \\
\text { Laos, Latvia, Lebanon, Libya, Macau, Maldives, Marshall Islands, Mauritius, } \\
\text { Mexico, Micronesia, Mongolia, Morocco, Nauru, Netherlands, Netherlands } \\
\text { Antilles, New Caledonia, New Zealand, Nicaragua, Norway, Oman, Papua New } \\
\text { Guinea, Paraguay, Peru, Philippines, Puerto Rico, Saint Barthelemy, Saint Helena, } \\
\text { Saint Pierre and Miquelon, Samoa, Saudi Arabia, Slovakia, Solomon Islands, Sudan, } \\
\text { Switzerland, Tajikistan, Thailand, Timor-Leste, Tonga, Turkey, Turkmenistan, Turks } \\
\text { and Caicos Islands, Tuvalu, United Arab Emirates, United Kingdom, United States, } \\
\text { Vanuatu, Venezuela, Wallis and Futuna, Yemen }\end{array}$ & 88 \\
\hline 106 & $\begin{array}{l}\text { American Samoa, Australia, Belarus, Bulgaria, Burma, Canada, Colombia, Croatia, } \\
\text { Cuba, Czech Republic, Denmark, Estonia, European Union, Gaza Strip, Germany, } \\
\text { Greece, Guam, Hungary, Japan, Jordan, Kazakhstan, N Korea, Lithuania, Malta, } \\
\text { Moldova, Monaco, Nigeria, Northern Mariana Islands, Palau, Poland, Qatar, } \\
\text { Romania, Russia, Saint Kitts and Nevis, Saint Lucia, Sweden, Syria, Ukraine, United } \\
\text { States Virgin Islands, Uzbekistan, West Bank }\end{array}$ & 41 \\
\hline 107 & $\begin{array}{l}\text { Andorra, Bosnia and Herzegovina, Faroe Islands, Gibraltar, Ireland, Italy, Korea, } \\
\text { South, Luxembourg, Malaysia, Montenegro, Portugal, Serbia, Slovenia, Spain, } \\
\text { Suriname, Tunisia, Vietnam }\end{array}$ & 14 \\
\hline 108 & Hong Kong, Jersey, Macedonia, Singapore & 4 \\
\hline 109 & San Marino, Taiwan & 2 \\
\hline 110 & Grenada, Pakistan & 2 \\
\hline 111 & Georgia & 1 \\
\hline 112 & Albania, Armenia, Azerbaijan, India & 4 \\
\hline 113 & China & 1 \\
\hline
\end{tabular}

For better understanding, the distribution of countries as per sex ratios and age group is presented in Table 3. For further elucidation of facts, central tendencies (mean, median, and mode), standard deviation, and percentiles of sex ratio, at birth, for population below 15 years of age, 1564 years of age, and 65+ years of age and for total population were calculated and are displayed in Table 4. It is apparent that mean sex ratio declines as age increases. At birth it is 105 $( \pm 2)$; for population below 15 years of age, it is $104( \pm 3)$; for age group 15-64 years, it is $102( \pm 18)$, whereas, after 65 years of age, the population of females exceeds males. The mean sex ratio calculated for $65+$ years' age group is $80( \pm 18)$ with a minimum of 44 , and 87 is the 75 th percentile.

In world population of 7 billion people, India and China are contributing $36.9 \%$. India alone has a share of $17.5 \%$.
Every sixth person in the world is an Indian. It is a matter of serious concern that, in both countries, the population of females is declining rapidly. According to estimation, a total of 37.25 million Indian males will remain without partner. If we look into the child sex ratio of 0-6 years' age group, it is further a serious concern that there are 914 girls for every 1000 boys. It clearly indicates the prevalence of female foeticide and infanticide in India. The analysis of past censuses clearly exhibits that there is continuous decline in the child sex ratio in India. In 1961 the sex ratio of 0-6 years was 976 females per thousand of males, which has declined in every census and reached 914 in 2011.

To know the trend of sex ratio in India, the data of past 110 years was analyzed. The analysis gives a declining trend (Figure 1). The comparison of sex ratio of $0-6$ years and the 
TABLE 2: Sex ratio (number of males per 100 females) at birth (2011) around the globe.

\begin{tabular}{lccc}
\hline Sex ratio & $\begin{array}{c}\text { Number of } \\
\text { countries }\end{array}$ & Percent & $\begin{array}{c}\text { Cumulative } \\
\text { frequency }\end{array}$ \\
\hline 101 & 3 & 1.3 & 3 \\
102 & 7 & 3.1 & 10 \\
103 & 45 & 19.8 & 55 \\
104 & 12 & 5.3 & 67 \\
105 & 88 & 38.8 & 155 \\
106 & 41 & 18.1 & 196 \\
107 & 17 & 7.5 & 213 \\
108 & 4 & 1.8 & 217 \\
109 & 2 & 0.9 & 219 \\
110 & 2 & 0.9 & 221 \\
111 & 1 & 0.4 & 222 \\
112 & 4 & 1.8 & 226 \\
113 & 1 & 0.4 & 227 \\
\hline Total & 227 & 100 & \\
\hline
\end{tabular}

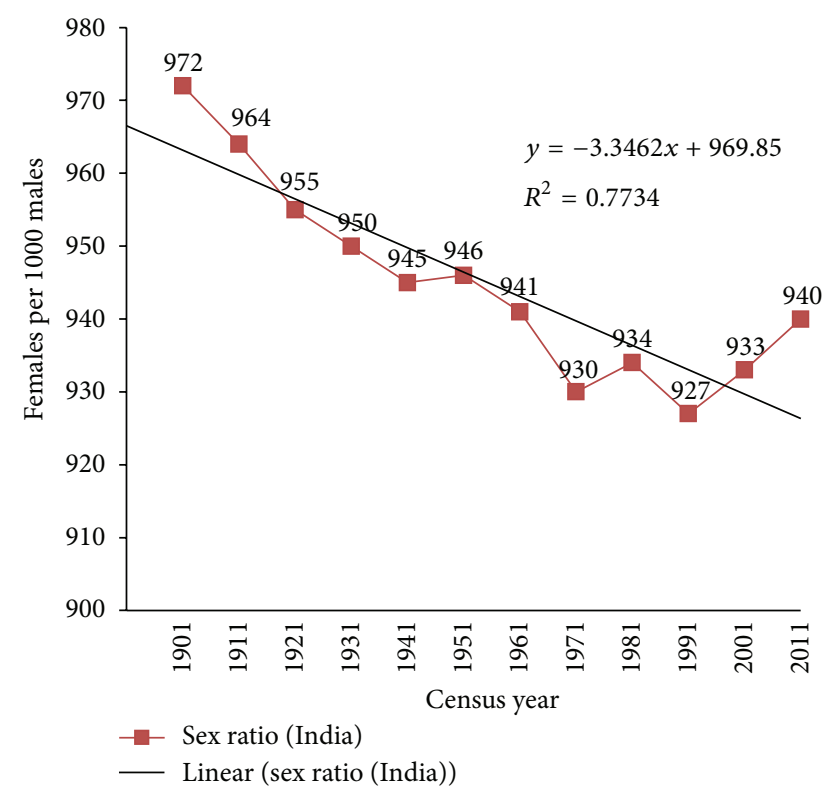

FIGURE 1: Sex ratio among Indians during 1901-1911.

total population is further a matter of serious concern as it is declining census by census (Figure 2). If this trend continues, the sex ratio of total population will also decline because it is determined by the sex ratio at birth and the child sex ratio.

The above description indicates that there is sex imbalance in major parts of the world. The population of females is declining especially in the highly populated regions. Asian countries are more prone to this problem. There may be various factors responsible for sex imbalance, namely, socioeconomic, political, demographic, biological, and so forth. To know the correlation between sex ratios and variables, like human development index, gender inequality index, life expectancy at birth, fertility, mortality, and migration, the

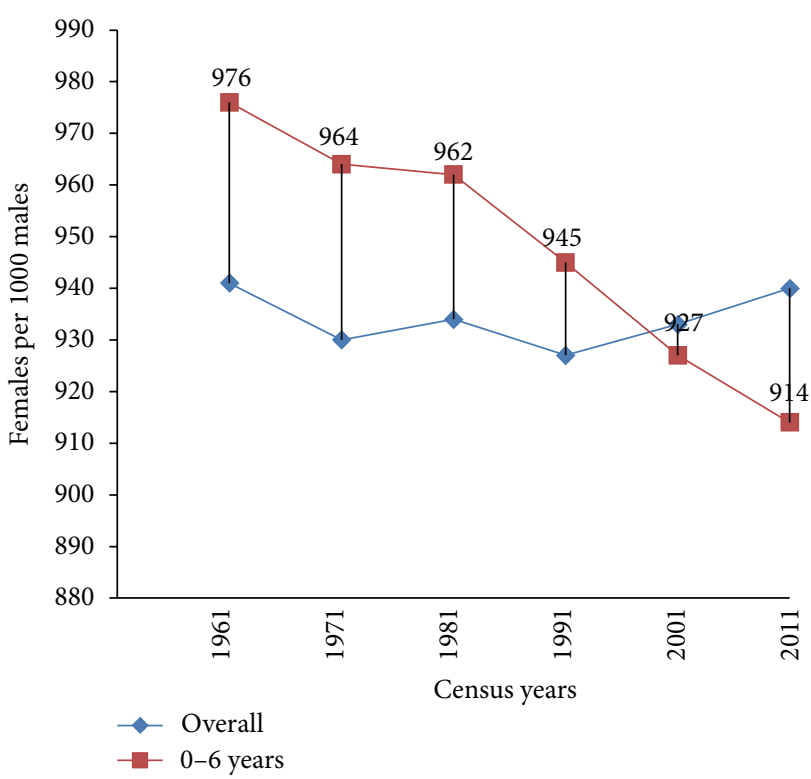

FIgURE 2: Sex ratio among total population and children of 0-6 years.

population growth rate bivariate correlation was computed for 183 countries, as displayed in Table 5. The analysis indicates that the sex ratio at birth is significantly correlated with the sex ratio of population $0-15$ years of age $(r=0.847)$, life expectancy at birth $(r=0.471)$, and human development index $(r=0.420)$. These correlations are positive and significant at $1 \%$ level $(P<0.001)$. These findings leads to conclude that the female population is declining especially in those countries where human development index is good and life expectancy is higher. Further, it leads to conclude that where literacy is higher and health facilities are better, female foeticide is being practiced. On the other hand, gender inequality index, fertility, and rate of natural increase of population have inverse correlation with the sex ratio at birth. These correlations are negative and significant at $1 \%$ level $(P<0.001)$.

To know the determinants of the sex ratio at birth, bivariate linear regression analysis was computed keeping the sex ratio at birth as dependent (Table 6). It is evident that the sex ratio at birth is highly dependent $(71.8 \%)$ on sex ratio of population of $0-15$ years of age $\left(r^{2}=0.718 ; P<0.001\right)$. The analysis indicates that the sex ratio at birth is not a recent phenomenon but it is an outcome of past and for last 15 years, similar trend is continuing. It can also be inversely interpreted as the sex ratio of the population of $0-15$ years of age is highly dependent on the sex ratio at birth. Further, the sex ratios at birth have no correlation with sex ratio of population of 1564 years of age, population of $65+$ years, and total population. It indicates that almost 15 years ago there was equilibrium in the sex ratio. Otherwise, similar trend may have exhibited by the sex ratio of population of $15+$ years of age.

Further the regression analysis (Table 6) shows that total fertility rate (TFR), crude birth rate (CBR), life expectancy at birth, adolescent fertility rate, rate of natural increase 
TABLE 3: Sex ratio (number of males per 100 females) among the population of different age group.

\begin{tabular}{|c|c|c|c|c|}
\hline \multirow{2}{*}{ Sex ratio } & Pop. aged $65+$ & $15-64$ years & $0-15$ years & Total population (age $0-120$ ) \\
\hline & \multicolumn{4}{|c|}{ Number of countries } \\
\hline$<50$ & 6 & & & \\
\hline $51-60$ & 10 & & & \\
\hline $61-70$ & 44 & 1 & & \\
\hline $71-80$ & 70 & 1 & & 1 \\
\hline $81-90$ & 57 & 10 & & 11 \\
\hline $91-100$ & 24 & 115 & 13 & 144 \\
\hline 101-105 & 4 & 73 & 159 & 49 \\
\hline $106-110$ & 5 & 13 & 47 & 12 \\
\hline $111+$ & 7 & 14 & 8 & 10 \\
\hline Total & 227 & 227 & 227 & 227 \\
\hline
\end{tabular}

TABLE 4: Central tendencies, standard deviation, and percentiles of sex ratio.

\begin{tabular}{|c|c|c|c|c|c|}
\hline & Sex ratio at birth & $\begin{array}{c}\text { Sex ratio of } \\
0-15 \text { yrs }\end{array}$ & $\begin{array}{c}\text { Sex ratio of } \\
15-64 \text { yrs }\end{array}$ & $\begin{array}{c}\text { Sex ratio of } \\
65+\text { yrs }\end{array}$ & $\begin{array}{l}\text { Sex ratio for } \\
\text { total population }\end{array}$ \\
\hline$N$ & 227 & 227 & 227 & 227 & 227 \\
\hline Mean & 105 & 104 & 102 & 80 & 100 \\
\hline Median & 105 & 104 & 100 & 78 & 99 \\
\hline Mode & 105 & 104 & 100 & 76 & 99 \\
\hline $\mathrm{SD}$ & 2 & 3 & 18 & 18 & 13 \\
\hline Minimum & 101 & 96 & 67 & 44 & 74 \\
\hline Maximum & 113 & 117 & 274 & 195 & 219 \\
\hline \multicolumn{6}{|l|}{ Percentiles } \\
\hline 25 & 104 & 103 & 97 & 70 & 96 \\
\hline 50 & 105 & 104 & 100 & 78 & 99 \\
\hline 75 & 106 & 105 & 103 & 87 & 101 \\
\hline 99 & 112 & 115 & 227 & 178 & 187 \\
\hline 100 & 113 & 117 & 274 & 195 & 219 \\
\hline
\end{tabular}

$N$ stands for number of countries.

SD stands for standard deviation.

of population, human development index (HDI), infant mortality rate (IMR), gender inequality index, and crude death rate (CDR) have significant impact on the sex ratio at birth. Seven of these variables, namely, total fertility rate, crude birth rate, adolescent fertility rate, rate of natural increase, infant mortality rate, gender inequality index, and crude death rate, have inverse effect, and they account for $24.4 \%, 23.1 \%, 18.8 \%, 18.9 \%, 16.3 \%, 16.1 \%$, and $5.1 \%$ of variability, respectively. Simultaneously, life expectancy at birth and human development index have positive impact on sex ratio at birth; they account for $22.2 \%$ and $17.7 \%$ variability correspondingly.

For further elucidation of facts stepwise multivariate regression analysis was computed which gave different model and predictors (Table 7). The analysis started with keeping the sex ratio at birth as dependent and 14 variables as independent. Initially it gives single model, according to which sex ratio at birth is determined by sex ratio of $0-15$ years of age group, which accounts for 81.9 percent variability. Here, it should be interpreted vice versa. The analysis again gives single model, according to which the predictor is total fertility rate (TFR), which alone accounts for $23.7 \%$ variability. After removal of TFR, the crude birth rate (CBR) becomes the sole predictor, which accounts for $23.6 \%$ variability. In the next step, when CBR too is removed, the life expectancy at birth emerges as sole predictor, which accounts for $22.9 \%$ variability; but when it is removed, the analysis gives four models. According to first model, the predictor is adolescent fertility rate, which alone can account for $19.7 \%$ variability on the sex ratio at birth. According to second model, there are two predictors, namely, adolescent fertility rate and rate of natural increase, and they together account for $22.4 \%$ variability. According to third model, there are three predictors, namely, adolescent fertility rate, rate of natural increase, and crude death rate. These predictors account for $25 \%$ variability. According to fourth model, there are two predictors, namely, rate of natural increase of population and crude death rate, and they together account for $24.6 \%$ variability. Furthermore computation and removal of these predictors give up three single models, according to which 


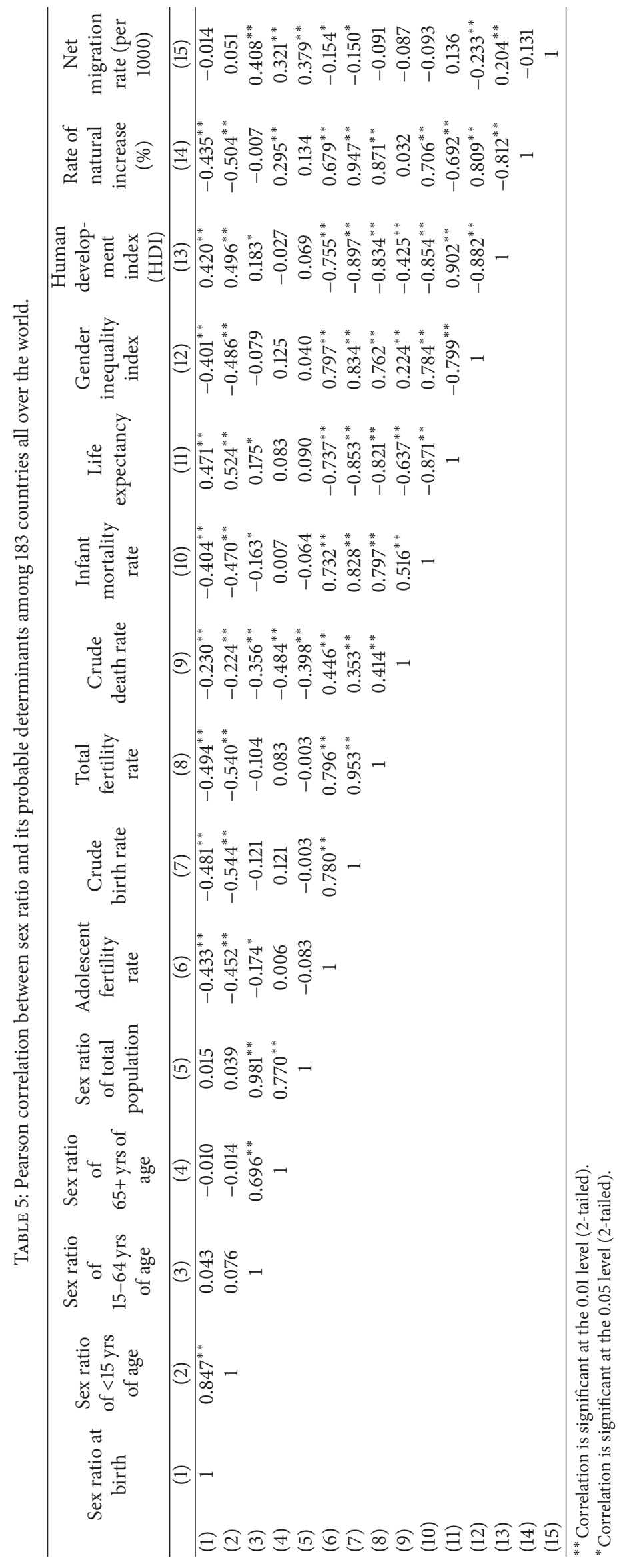


TABLE 6: Regression analysis between sex ratio and other demographic variables among 183 countries of the world.

\begin{tabular}{llcccccc}
\hline & & \multicolumn{2}{c}{ Bivariate linear regression analysis } & & & \\
Dependent variable & Independent variable & $R^{2}$ & $\mathrm{~B} \pm \mathrm{SE}$ & $\mathrm{df}$ & $F$-value & $t$-value & $P$ value \\
\hline & Sex ratio of 0-15 years of age & 0.718 & $0.596 \pm 0.028$ & 182 & 459.9 & 21.4 & 0.001 \\
& Total fertility rate & 0.244 & $-0.723 \pm 0.097$ & 174 & 55.8 & -7.4 & 0.001 \\
& Crude birth rate (CBR) & 0.231 & $-0.088 \pm 0.012$ & 182 & 54.4 & -7.3 & 0.001 \\
& Life expectancy at birth & 0.222 & $0.096 \pm 0.013$ & 182 & 51.5 & 7.1 & 0.001 \\
& Adolescent fertility rate & 0.188 & $-0.019 \pm 0.003$ & 182 & 41.7 & -6.4 & 0.001 \\
& Rate of natural increase (\%) & 0.189 & $-0.846 \pm 0.130$ & 182 & 42.1 & -6.4 & 0.001 \\
& Human development index & 0.177 & $4.812 \pm 0.772$ & 182 & 38.8 & 6.2 & 0.001 \\
& Infant mortality rate (IMR) & 0.163 & $-0.026 \pm 0.004$ & 182 & 35.2 & -5.9 & 0.001 \\
& Gexder inequality index & 0.161 & $-4.336 \pm 0.367$ & 142 & 26.9 & -5.1 & 0.001 \\
& Crude death rate (CDR) & 0.053 & $-0.130 \pm 0.041$ & 182 & 10.1 & -3.1 & 0.002 \\
& Sex ratio of 15-64 years of age & 0.002 & $0.004 \pm 0.008$ & 182 & 0.3 & 0.6 & 0.560 \\
& Sex ratio of population 65+ & 0 & $-0.001 \pm 0.009$ & 182 & 0.01 & -0.13 & 0.894 \\
& Sex ratio of total population & 0 & $0.002 \pm 0.011$ & 182 & 0.04 & 0.2 & 0.837 \\
& Net migration rate (per 1000) & 0 & $-0.006 \pm 0.030$ & 182 & 0.03 & -0.1 & 0.852 \\
\hline
\end{tabular}

TABLE 7: Stepwise multivariate regression analysis (started with all the above variables).

\begin{tabular}{|c|c|c|c|c|c|c|c|}
\hline Model & Predictor & $R^{2}$ & $\mathrm{~B} \pm \mathrm{SE}$ & $\mathrm{df}$ & $F$-value & $t$-value & $P$ value \\
\hline 1 & Sex ratio of $0-15$ years of age & 0.819 & $0.642 \pm 0.025$ & 142 & 640.0 & 25.2 & 0.001 \\
\hline \multicolumn{8}{|c|}{ After removal of sex ratio of $0-15$ years of age } \\
\hline 1 & Total fertility rate & 0.237 & $-0.741 \pm 0.112$ & 142 & 43.8 & -6.6 & 0.001 \\
\hline \multicolumn{8}{|c|}{ After removal of total fertility rate } \\
\hline 1 & Crude birth rate & 0.236 & $-0.091 \pm 0.014$ & 142 & 43.6 & -6.6 & 0.001 \\
\hline \multicolumn{8}{|c|}{ After removal of crude birth rate } \\
\hline 1 & Life expectancy at birth & 0.229 & $0.098 \pm 0.015$ & 142 & 41.9 & 6.4 & 0.001 \\
\hline \multicolumn{8}{|c|}{ After removal of life expectancy at birth } \\
\hline 1 & Adolescent fertility rate & 0.197 & $-0.020 \pm 0.003$ & 142 & 34.6 & -5.8 & 0.001 \\
\hline \multirow{2}{*}{2} & Adolescent fertility rate & \multirow{2}{*}{0.224} & $-0.013 \pm 0.005$ & \multirow{2}{*}{142} & \multirow{2}{*}{20.2} & -2.6 & \multirow{2}{*}{0.001} \\
\hline & Rate of natural increase (\%) & & $-0.460 \pm 0.208$ & & & -2.2 & \\
\hline \multirow{3}{*}{3} & Adolescent fertility rate & \multirow{3}{*}{0.250} & $-0.005 \pm 0.006$ & & & -0.9 & \multirow{3}{*}{0.001} \\
\hline & Rate of natural increase (\%) & & $-0.682 \pm 0.228$ & 142 & 15.4 & -0.3 & \\
\hline & Crude death rate (CDR) & & $-0.115 \pm 0.052$ & & & -0.2 & \\
\hline \multirow{2}{*}{4} & Rate of natural increase (\%) & \multirow{2}{*}{0.246} & $-0.846 \pm 0.146$ & \multirow{2}{*}{142} & \multirow{2}{*}{22.7} & -0.4 & \multirow{2}{*}{0.001} \\
\hline & Crude death rate (CDR) & & $-0.144 \pm 0.042$ & & & -0.2 & \\
\hline 1 & Human development index & 0.163 & $4.650 \pm 0.886$ & 142 & 27.5 & 5.2 & 0.001 \\
\hline 1 & Gender inequality index & 0.161 & $-4.336 \pm 0.835$ & 142 & 26.9 & -5.1 & 0.001 \\
\hline 1 & Infant mortality rate (IMR) & 0.163 & $-0.026 \pm 0.004$ & 182 & 35.2 & -5.9 & 0.001 \\
\hline
\end{tabular}

Note: values of all the variables were for the year 2011

the sole predictor of sex ratio at birth is human development index (HDI), gender inequality index, and infant mortality rate and they consecutively account for approximately equal variability, that is, around $16 \%$ each.

\section{Discussion}

The sex ratio at birth is 105 males per 100 females. This difference is apparently of biological origin. Yet, during last one century, it is being observed that the population of women folk at birth and in total population is proportionately declining. In India alone, there is difference of 3.7 crore (37255074) in the population of males and females. Such huge number of males would remain without partner. The analysis of past censuses clearly exhibits that, during last 110 years, the population of females has declined significantly.

The sex composition of a population plays a vital role, as it affects the incidence of births, deaths, and marriage and vice versa. The migration rates and almost all population characteristics, including socioeconomic characteristics and community life, are influenced by sex composition of population [20]. It is apparent from above description that, during last century, in many parts of the world including India and 
China, the population of females has declined as compared to males. The Asian countries are more prone to the problem, as in many countries, it is totally imbalanced. One of the major reasons of sex imbalance, in such countries, is male selective international migration. It is statistically proved that the sex ratio of 15-64 years of age has significant correlation with the net migration rate (NMR). The correlation coefficient $(r=408)$ is significant at $1 \%$ level. The countries which accommodate the emigrants have higher male population as compared to females.

\section{Conclusion}

Sex ratio is a measure of population composition. Theoretically, they should be equal in proportion. Practically, overall sex ratio of the world population is 101 males per 100 females. By nature, slightly more males are born than females.

On the basis of correlation and regression analysis, it can be concluded that population of females declined at birth in those countries or regions where human development index (HDI) is better and life expectancy is higher. In many of the Asian countries, there is strong cultural preference for son, which led to selective abortion of female fetuses. In this way, sex imbalance is increasing day by day in such regions all over the globe. Another major predictor of sex imbalance in higher age (15-64 years) is international migration. Generally males migrate in higher proportion, which is a cause of sex imbalance in both the countries, where they reach and from where they migrate.

Decline of female population may have various sociopolitical and demographic consequences. For example, a proportion of male population will remain unmarried. It will lead to strong competition among the mates. Prostitution and human trafficking like social problem may revive. The criminal cases of rape and murder may increase. At the same time, the declining population of females will be a natural mechanism of population control as the less number of wombs would be available for reproduction and in this way the fertility rate will decline, as apparent from correlation and regression analysis also. It can be suggested that the sex ratio should be monitored and female foeticide should not be tolerated to maintain the balance in sex ratio.

\section{Conflict of Interests}

The authors declare that there is no conflict of interests regarding the publication of this paper.

\section{References}

[1] A. Liker, R. P. Freckleton, and T. Székely, "The evolution of sex roles in birds is related to adult sex ratio," Nature Communications, vol. 4, article 1587, 2013.

[2] J. J. Bull, "Sex ratio evolution when fitness varies," Heredity, vol. 46, no. 1, pp. 9-26, 1981.

[3] C. Packer, D. A. Collins, and L. E. Eberly, "Problems with primate sex ratios," Philosophical Transactions of the Royal Society B: Biological Sciences, vol. 355, no. 1403, pp. 1627-1635, 2000.
[4] L. E. B. Kruuk, T. H. Clutton-Brock, S. D. Albon, J. M. Pemberton, and F. E. Guinness, "Population density affects sex ratio variation in red deer," Nature, vol. 399 , no. 6735 , pp. 459$461,1999$.

[5] S. A. West, S. E. Reece, and B. C. Sheldon, "Sex ratios," Heredity, vol. 88, no. 2, pp. 117-124, 2002.

[6] T. Madsen and R. Shine, "Sexual competition among brothers may influence offspring sex ratios in snakes," Evolution, vol. 46, no. 5, pp. 1549-1552, 1992.

[7] J. Komdeur, S. Daan, J. Tinbergen, and C. Mateman, "Extreme adaptive modification in sex ratio of the Seychelles Warbler's eggs," Nature, vol. 385, no. 6616, pp. 522-525, 1997.

[8] S. Creel, N. M. Creel, and S. L. Monfort, "Birth order, estrogens and sex-ratio adaptation in African wild dogs (Lycaon pictus)," Animal Reproduction Science, vol. 53, no. 1-4, pp. 315-320, 1998.

[9] B. C. Sheldon, "Recent studies of avian sex ratios," Heredity, vol. 80, no. 4, pp. 397-402, 1998.

[10] R. G. Nager, P. Monaghan, R. Griffiths, D. C. Houston, and R. Dawson, "Experimental demonstration that offspring sex ratio varies with maternal condition," Proceedings of the National Academy of Sciences of the United States of America, vol. 96, no. 2, pp. 570-573, 1999.

[11] B. C. Sheldon, S. Andersson, S. C. Griffith, J. Örnborg, and J. Sendecka, "Ultraviolet colour variation influences blue tit sex ratios," Nature, vol. 402, no. 6764, pp. 874-877, 1999.

[12] L. Aviles, J. McCormack, A. Cutter, and T. Bukowski, "Precise, highly female-biased sex ratios in a social spider," Proceedings of the Royal Society B: Biological Sciences, vol. 267, no. 1451, pp. 1445-1449, 2000.

[13] Y. Sakisaka, T. Yahara, I. Miura, and E. Kasuya, "Maternal control of sex ratio in Rana rugosa: evidence from DNA sexing," Molecular Ecology, vol. 9, no. 11, pp. 1711-1715, 2000.

[14] M. Olsson and R. Shine, "Facultative sex allocation in snow skink lizards (Niveoscincus microlepidotus)," Journal of Evolutionary Biology, vol. 14, no. 1, pp. 120-128, 2001.

[15] R. K. Gautam, Population characteristics of middle and high altitude Kinnaura of Kinnaur district, Himachal Pradesh, India [Ph.D. thesis], University of Delhi, 2006.

[16] R. K. Gautam, A. K. Kapoor, and G. K. Kshatriya, "Natural selection among Kinnaura of the Himalayan highland: a comparative analysis with other Indian and Himalayan populations," Indian Journal of Human Genetics, vol. 15, no. 3, pp. 125-136, 2009.

[17] R. K. Gautam, G. K. Kshatriya, and A. Kapoor, Population Ecology and Family Planning: A Demographic Anthropology of Himalayan Population, Kinnaura, Serials Publications, New Delhi, India, 2010.

[18] R. K. Gautam and G. K. Kshatriya, "Polyandry: a case study of Kinnauras," Indian Journal of Physical Anthropology and Human Genetics, vol. 30, no. 1-2, pp. 145-161, 2011.

[19] R. K. Gautam and G. K. Kshatriya, "Existence and relevance of polyandry among Indian tribes with special reference to Kinnauras of Himalayan highlands," in Anthropology in Contemporary Societies, A. N. Sharma and S. K. Rawat, Eds., Sarup Book Publishers, New Delhi, India, 2013.

[20] M. K. Jain, "Growing imbalance in the sex composition of India," Demographic India, vol. 4, no. 2, 1975. 

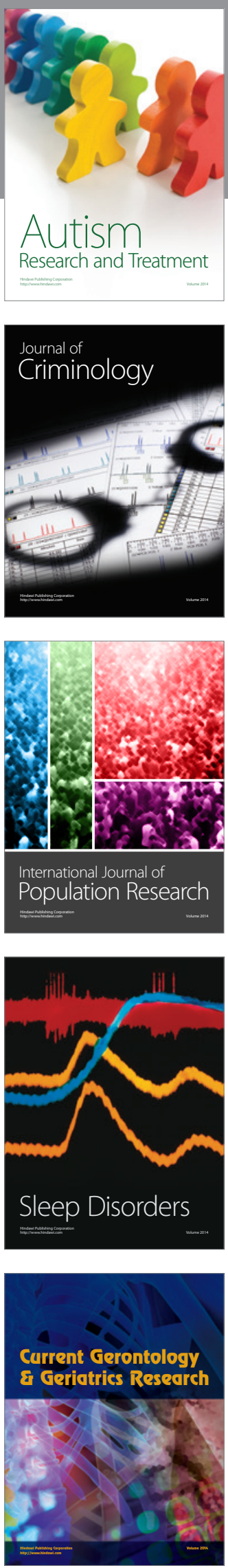
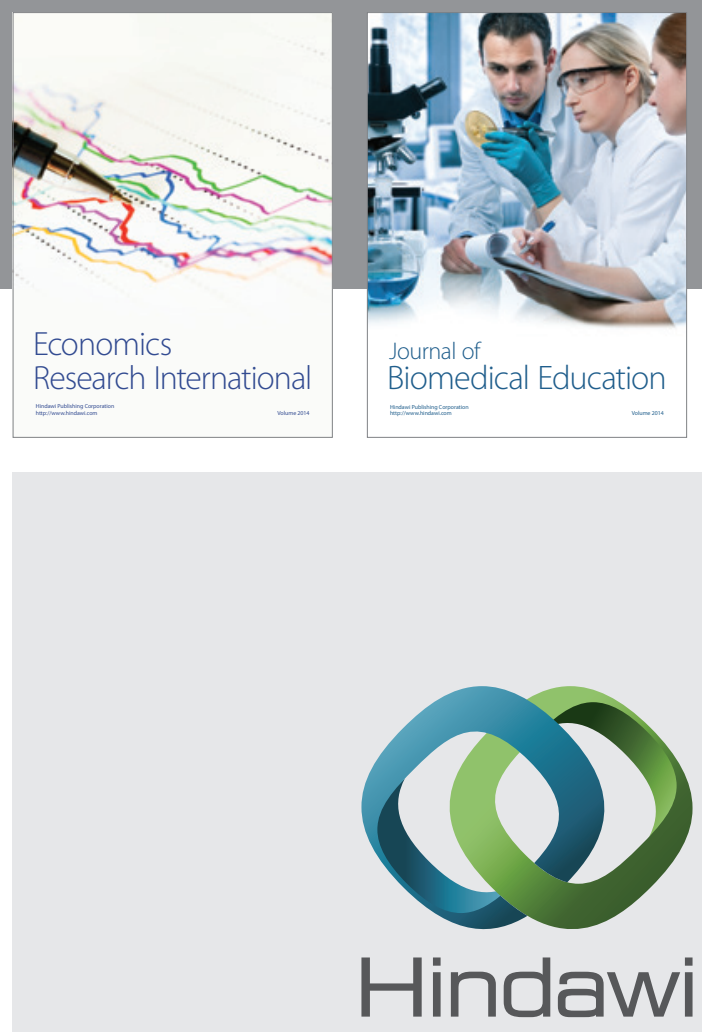

Submit your manuscripts at

http://www.hindawi.com
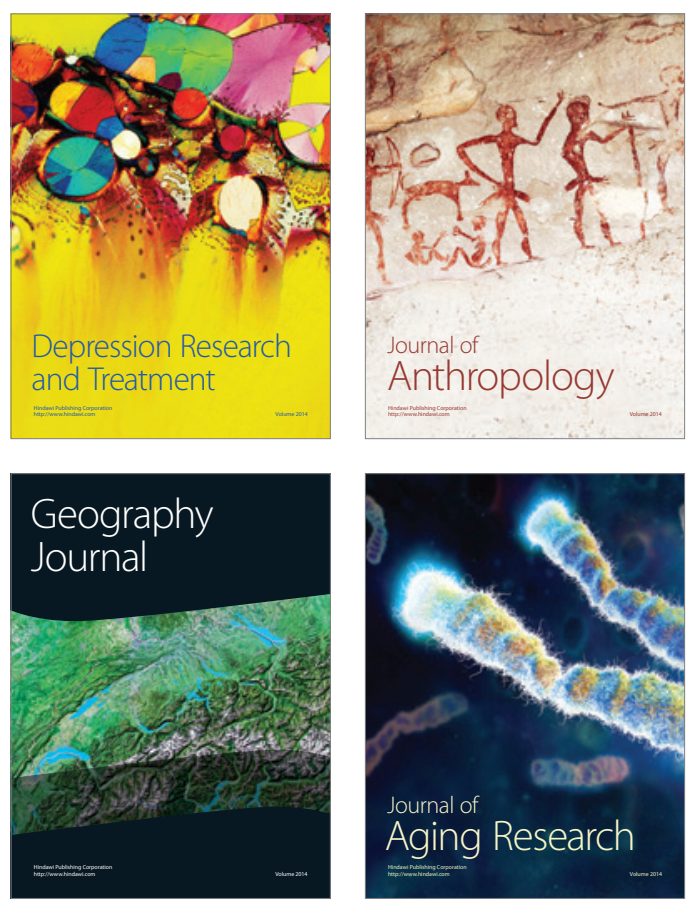
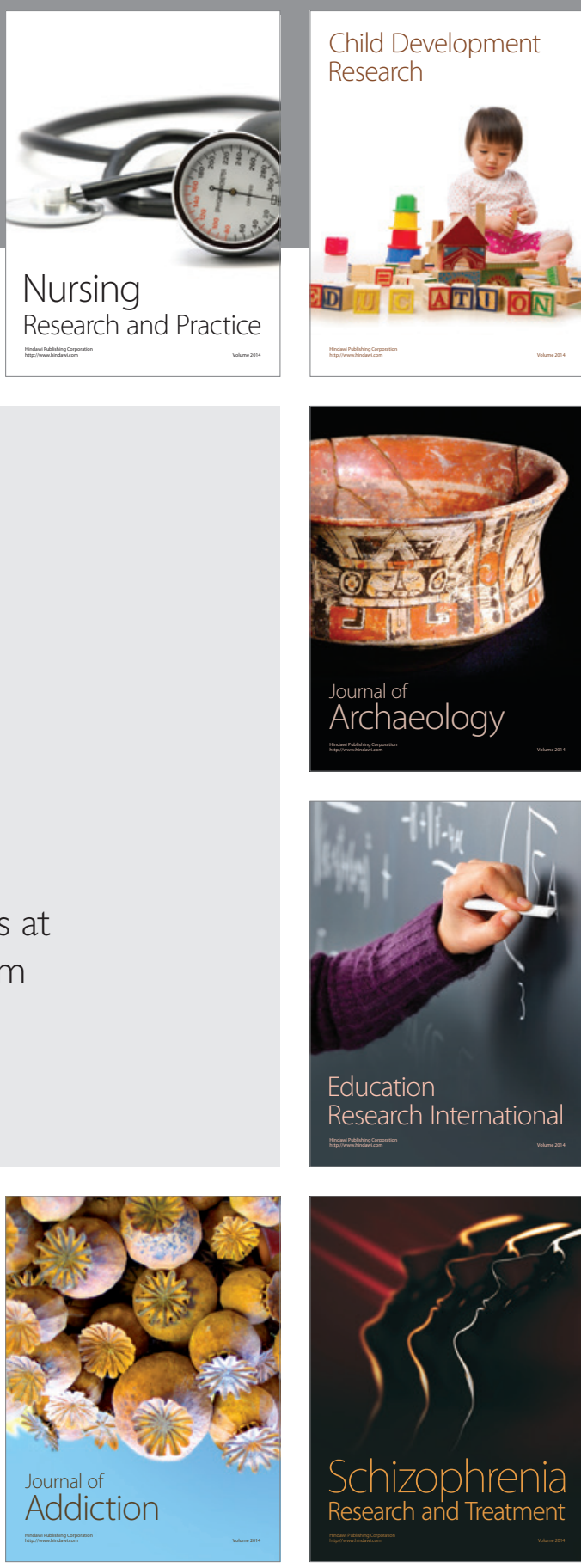

(D)
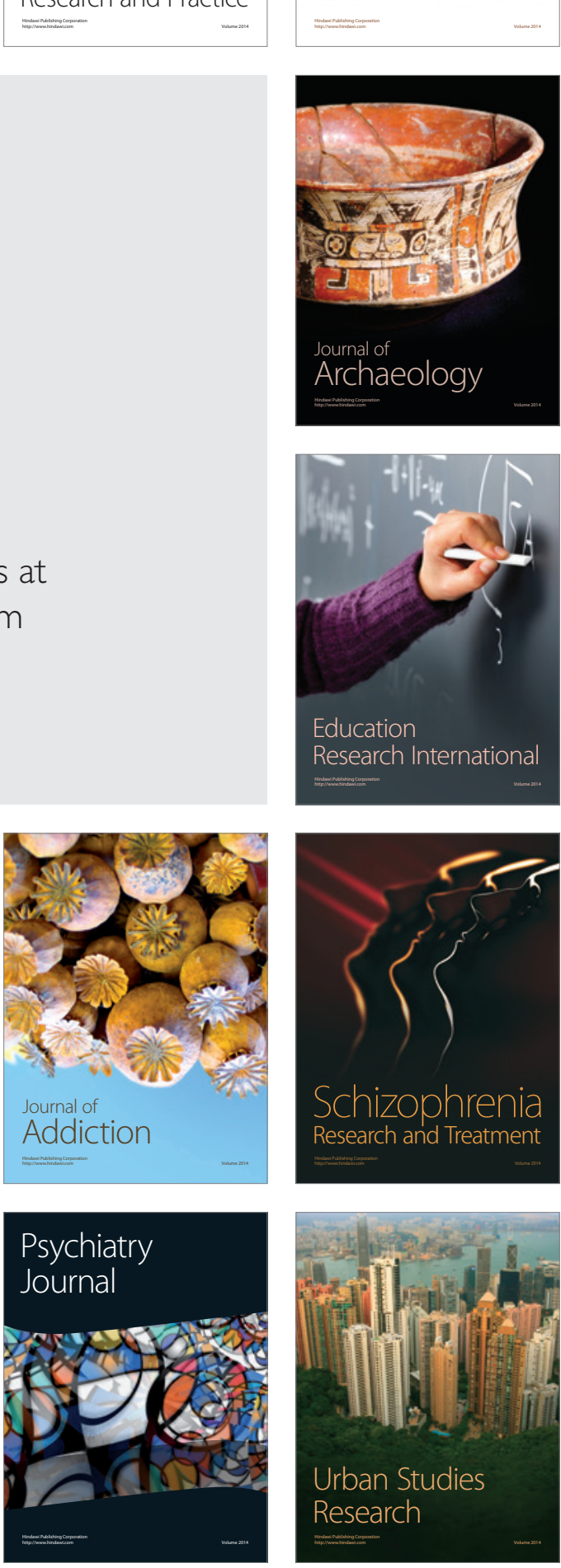